\title{
Which Factors do Parents of Offspring with Intellectual Disability Experience as Promoting Inclusive Education for their Children? ${ }^{1}$
}

\author{
Carl Chr. Bachke*
}

University of Agder, Norway, PO Box 509, 4898 Grimstad, Norway

\begin{abstract}
The background of this research is that few studies on inclusive education internationally, use parents as informants. Even fewer emphasize their positive experiences only. From the Norwegian support organisation for people with intellectual disability 14 parent-members were selected and qualitatively interviewed about their positive experiences with inclusive education for their offspring. By means of a discourse analytic approach their statements about constructive factors were benchmarked with twelve formerly identified literature-based factors in order to investigate which of twelve factors were validated by parental experiences, and to detect possible new factors.

The general research question illuminated is which factors do parents of offspring with intellectual disability experience as promoting inclusive education for their children? The results are linked to the following four sub-questions: (1) which of the factors, disclosed in current literature, is frequently mentioned by the informants; (2) which new factors are disclosed; (3) which factor is so frequently mentioned that it is considered substantial; and (4) which factors might be combined, and possibly renamed?

The results show that the informants contributed all in all with 18 factors. In the discussions it was argued that five factors were interpreted as new, four factors proved to be substantial, that a fifth factor almost gained equal status, while three more factors were considered vital. These eight factors represented the main answer to the research question, and were summarised in metaphoric model, baptized" the school-house of inclusive education".
\end{abstract}

Keywords: Inclusion, learning disability, parental experiences, successful factors, empirical-pragmatic perspective, metaphoric model.

\section{INTRODUCTION}

The notion of inclusion has gained popularity over the last 40 years. It relates to an ideology affecting most community sectors, and has become a political concept, both nationally and internationally. The inclusion wave bears in its midst values like social justice, equality and acceptance. Its discourses go far beyond the field of education [1-3]. An expressed aim of the discourses is to help future youngsters to, in a better way, embrace human variations than former generations. Education, and particularly special education, is seen as a major tool to attain this ultimate goal $[2,4]$.

Coming to research on inclusion/inclusive education $^{2}$ (here mostly used synonymously) one is faced with the fact that these concepts are complex and have many meanings, which affect research in the field $[2,3]$. Based on literature reviews Bachke $[5,6]$ launches his own definition of inclusion. It is used both to explicate what is meant by the concept in this study, and to increase the concept-validity during the interviews (introductory it was presented to the informants):

*Address correspondence to this author at the University of Agder, Norway, PO Box 509, 4898 Grimstad, Norway; Tel: +47 37233 375; Mob: + 4797582 538; E-mail: carl.c.bachke@uia.no

${ }^{1}$ Intellectual Disability is throughout the article abbreviated to ID.

${ }^{2}$ Inclusive education "covers a variety of attempts at providing for th whole diversity of pupils' educational needs in neigbouring schools." [2, p.7].
"Inclusion strives to become a bridge between normal ${ }^{3}$ and special teaching so every pupil can be met according to his/her needs, and at the same time experience a belonging to the school's/class' fellowship." [6, p.347]

However, one should observe a controversial aspect with this value-laden concept. It mostly emphasizes the individual approach to inclusion (cf. every pupil), which when implemented easily might lead to exclusion. Another part of this subject's conceptual mess is the question of which perspective of inclusion-research one should adhere to. Different ways of classifying perspectives exist [3, 7]. Haug [3] launches the dichotomy macro-/micro-perspective. The former looks into the structural and organizational hallmarks of the school system; for instance placement of pupils with special needs in either segregated schemes or in mainstreamed provisions. The latter [7] focuses more on how inclusive education is practised in the classrooms. Within this micro-perspective approach one might as a researcher wear "diagnostic glasses" either focusing on what is bad practice, in health language, what has a stigma of pathogenesis; or

\footnotetext{
${ }^{3}$ In this connection normal refers to mainstream teaching, i.e. teaching that does not require extra manpower, equipment or other resources.
} 
paying attention to what makes things work out well (best-practice-approach, [8]). The pathogenic approximation is similar to Tetler's critical perspective [7], while the best-practice-approach is a vital part of what Tetler calls the pragmatic perspective. This bestpractice-approach is also attempting to create a form of evidenced-based-like research perspective in the complex ideologically value-infested inclusion-field. Subsequently, this study aims at illuminating concrete factors, experienced by parents of offspring with ID, as promoting inclusive education for their children.

This choice of a pragmatic perspective was basically motivated by the fact that most published Scandinavian studies maintain a critical perspective. Secondly, so far only one Nordic study on inclusive education has partly used parent-informants [2]. This study had sampled parents from four European countries, but did also use other informants, like teachers. Therefore this study becomes the first Scandinavian research using Norwegian parents as the only informants. Subsequently, this research question is illuminated: Which factors do parents of offspring with intellectual disability experience as promoting inclusive education for their children? To throw light on this rather massive research question these four subquestions are deduced and looked at one by one before answering the overall research question:

1. Which of the factors, disclosed in current literature, are frequently mentioned by the informants?

\section{Which new factors are expressed?}

3. Which factor is so frequently mentioned that it is considered substantial?

4. Which factors might be combined, and possibly renamed?

Some key concepts of the research questions need clarification: Parents refers to biological parents who have been caretakers for their child from birth and onwards. No foster- or step-parent is included in the sample of informants, not intentionally, but as a result of the way informants were made available for the researcher. Children mean offspring of these parentinformants without any limitation related to the age of the child (children's age varies between 10 and 44 years). Intellectual disability (ID) is defined synonymously with the World Health Organization's; ICD-10 definition of mental retardation, F70-79:
Mental retardation is a condition of arrested or incomplete development of the mind, which is especially characterized by impairment of skills manifested during the developmental period, which contribute to the overall level of intelligence, i.e. cognitive, language, motor, and social abilities [9].

The concept frequently mentioned equals the concept substantial (cf. sub-question 3), and is defined by two criteria: (1) The factor is mentioned by parentinformants in at least ten statements; and (2) it must also be mentioned by half of the sample of the informants; i.e. 7 different persons.

\section{PROMOTING FACTORS IN CURRENT LITERATURE}

Research on concrete factors is scarce compared to the public attention the political discourse on inclusion at times generates. Accordingly theoretical, analytic and ideological reviews of the subject are frequent compared to appearance of pragmatic, empirical-based studies [3, 6, 10,11]. Among the latter Eggertsdóttir et al. [2] did a thorough inquiry on what seem to facilitate inclusive education. Their main results relate to these factors:

1. Preparation for schooling.

2. Curricula and individual education plans (IEPs).

3. Classroom practice.

4. Collaboration and co-ordination.

5. Pupils' social interaction.

6. Home-school interaction.

7. Evaluation and reflection.

8. Support services.

9. Staff development.

Bachke $[5,6]$ made two systematic literature reviews on reported successful factors of inclusion. The results of the latter study [6] are presented in Table 1.

By combining the nine factors of Eggertsdóttir et al. [2] and the eight factors of Table 1 [6] a classification manual was constructed to analyse the factor-relevant statements of the present study. This was done in two steps. Firstly, it was looked for common factors in the two studies: Four were identified as common, and partly renamed, as seen in Table $\mathbf{2}$. Notice that factor 
Table 1: Factors Promoting Inclusive Education [6]

\begin{tabular}{|c|c|c|c|}
\hline $\begin{array}{l}\text { Informants of studies } \\
\text { Factors expressed in the studies }\end{array}$ & Parents & $\begin{array}{c}\text { Teachers, pupils, } \\
\text { etc. }\end{array}$ & Total \\
\hline Parents' attitudes towards inclusion & 7 & 2 & 9 \\
\hline Skills of interaction & 5 & 6 & 11 \\
\hline Qualities and qualifications of teachers & 4 & 12 & 16 \\
\hline Pupils' level and type of impairment & 3 & 1 & 4 \\
\hline Co-operation home-school & 2 & 3 & 5 \\
\hline Influence of overall frame factors & 2 & 4 & 6 \\
\hline Use and training of assistants & 1 & 3 & 4 \\
\hline Use of promising teaching methods & 0 & 5 & 5 \\
\hline Total number of factors mentioned & 24 & 36 & 60 \\
\hline
\end{tabular}

Table 2: Construction of Common Factors Found in the Literature Reviews; the Figures in Brackets Refer to the Factor's Number in the Classification Manual, cf. Figure 1

\begin{tabular}{|c|c|c|}
\hline Eggertsdóttir et al. (2005) factors & Bachke (2011) factors & $\begin{array}{c}\text { Comparison and construction of a common } \\
\text { labelled factor used in this study }\end{array}$ \\
\hline \hline Pupils' social interaction & Skills of interaction & Equal and labelled: (1) Skills of interaction \\
\hline Home-school collaboration & Co-operation home-school & Equal and labelled : (2) Co-operation home-school \\
\hline Classroom practice & Use of promising teaching methods & $\begin{array}{c}\text { Rather equal and labelled: (3) Particulars of classroom } \\
\text { practice }\end{array}$ \\
\hline Staff development & $\begin{array}{c}\text { Qualities and qualifications of teachers; } \\
\text { and use and training of assistants }\end{array}$ & $\begin{array}{c}\text { Rather equal and labelled: (4) Staff's qualities, } \\
\text { qualification and development }\end{array}$ \\
\hline
\end{tabular}

4, staff development, includes both qualities and qualifications of teachers and use and training of assistants of Table 1.

The four factors of Table 2 were given the digit 1-4 in Figure 1. It was expected that these four common factors also should be frequently mentioned by the parent-informants.

Secondly, Figure 1 contains additional factors shown in the two studies. They were identified, enlisted and numbered in sequence in this way: The remaining factors of Eggertdóttir et al. [2] were attributed the five digits 5-9, and Bachke's [6] remaining three factors were ascribed the figures $10-12$. The figure-manual is particularly used to answer sub-question 1, and consequently 2 as well.

\section{METHODS}

Basically this study applied a hermeneutic approach by use of qualitative interviews. Interviewing is a common method of generating knowledge in a virgin territory [12], which this field still is considered to be. Since beforehand it was developed an analytic tool
(Figure 1), and hypothesized that certain factors (1-4) were expected to be substantial; the analytic work was also quantitatively inspired. However, since this study focused on what parent-informants spoke of concerning this issue; it was relevant to see the method applied as a discourse analytic approach [13]. In fact the study to a great extent compares outcomes of parental discourses with outcomes of professionals' written discourses.

\section{Sampling of Informants}

Parents of offspring with ID have to a great extent been avant-gardes of inclusive education in Norway, as underlined by The Norwegian Association for Persons with Developmental Disabilities (NAPDD ${ }^{4}$ ) with many parent-members: "It is a national advocacy organization that fights for the inclusion of persons with developmental disabilities in society" [14]. The parentinformants admitted that they over time had experienced hardships, bureaucratic fights, harsh

${ }^{4}$ The organisation's Norwegian name is Norsk Forbund for Utviklingshemmede (NFU). 


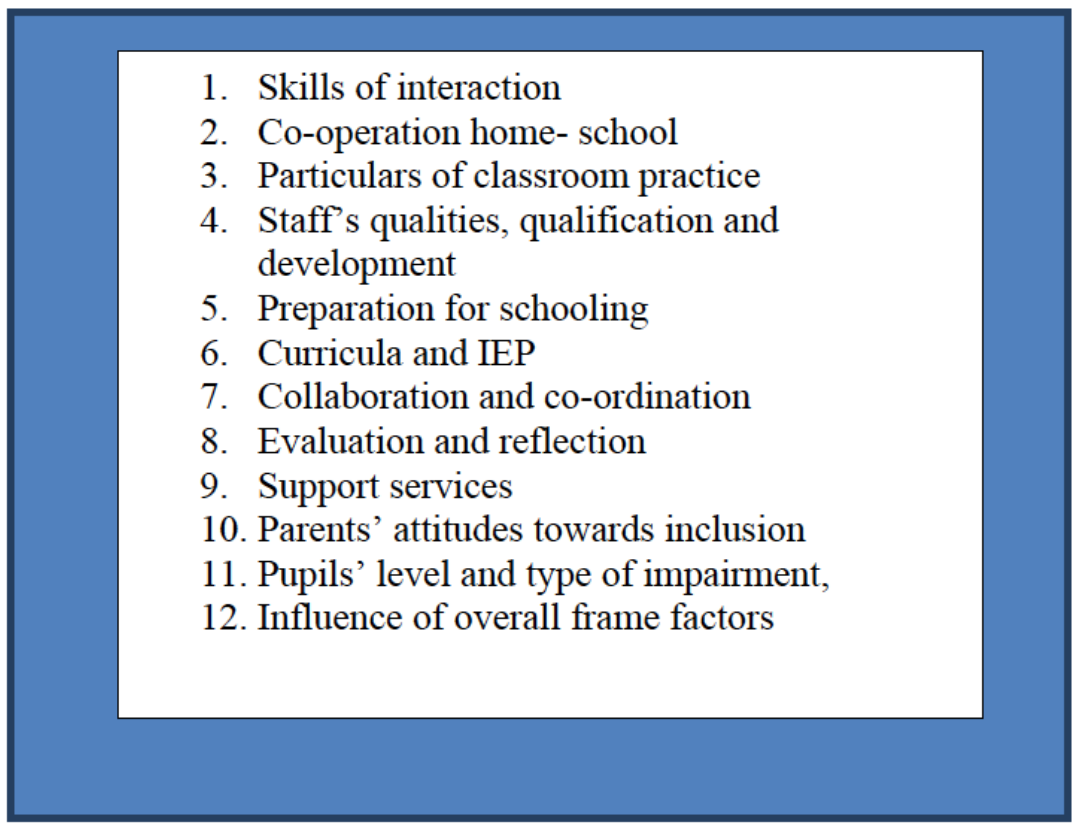

Figure 1: The factorial classification manual used for analysing the informants' statements.

discussions as well as successful change-agents in their struggle for achieving inclusive education. This fact made discourse analytic methodical concepts like discursive struggle and investigations of change [13] applicable when one listened to their stories. Thus parents were assumed to be good contributors of pointing out both recognisable and new attributing factors.

A combination of theoretical sampling procedure and network-sampling, both non-probability strategies, was used to select informants [15]. "Theoretical" referred to the fact that the researcher selected members of NAPDD in the two counties, East- and West-Agder, as his entire population.

The network-sampling was done in two steps. Firstly, the respective county-leaders were contacted both by phone and by e-mail. The phone call prepared the receivers for the e-mail, in which the interview guide and a letter of consent were enclosed. In the mail, the leaders were asked to select members from their county-organizations to participate. Secondly, the names were conveyed to the researcher who contacted the members on phone to confirm their willingness and to make appointments for the interviews. The leaders admitted that they had mostly asked people who were well-known to them, as rich sources of relevant information.

In total 16 persons participated; 5 from West-Agder and 11 from East-Agder. The researcher did not know whether the leaders contacted more than these 16 people, and whether some declined to participate. For ethical reasons he did not press the leaders to provide such information. Consequently, it was not possible to say anything about dropout rate, and how this sample mirrored the total population of NAPDD-members in Agder. One must thus be cautious in generalizing the findings.

\section{The Interview-Guide and Data Collection}

The interview-guide applied consisted of mainly open-ended questions, and contained two main-topics: (a) What kind of experiences did the parent-informants have with naming and changes in naming the diagnosis of ID (questions 2-7); and (b) descriptions of positive experiences of inclusion (question 8). Question 1 dealt with the demographics of the informants. The conversations with the informants adhered to the sequences of the questions. This article deals with question 8 and the sharing of parents' experiences with provisions, methods, frames, etc. that promoted the inclusion of their child at school. As an introduction to question 8 Bachke's definition of inclusion [6] was presented. The interview guide and the research guide were approved by NSD 2009, and the tape recorded material deleted by the end of the same year.

The interviews were carried out from June to October 2009. Three interviews were conducted at the researcher's university-office, one in a café, and twelve at informants' homes. Five out of six couples were 
interviewed jointly. Disturbances and disruptions during the interviews were few and not considered harmful for the data collection.

The researcher did the interviews himself. They were tape-recorded, except for an interview with a couple where hand written notes were made and typed out immediately after the conversation. For one of the couples from East-Agder it was later on discovered that the recorder failed to tape what was expressed by them on the inclusion-related question. Because of this the sample was reduced to 14 and the criterion (b) of frequently mentioned to seven. This latter number has been applied in the analyses connected to factorstatements.

To establish a relationship of confidence interviews started informally with greetings and small-talk. They proceeded to demographics of the informants and the naming of the diagnosis F70-79, before turning to the topic of inclusive education. This latter part of the interview had an average duration of 20 minutes. The interviews were transcribed soon afterwards. The transcript produced 82 pages of text, out of which half dealt with inclusive education.

\section{Analyses of Data}

The transcript was reread several times. To interpret the text a selective or focused codification was used [16, 17], based on the summarized twelve factors of Figure 1. In addition, the researcher paid particular attention to examples of successful practices at schools, and disregarded stories of malpractice. Both concretely articulated factors and the best-practice aspect were subsequently vital for categorizing textdata. Moreover, he also looked for any new factors articulated by the informants - to challenge the fertility of the study. Since this sample consisted only of 14 people, there was practically no basis for serious statistical estimates. However, some counting was done to check which factors qualified for substantiality. Such mixed analyses of data, qualitative as well quantitative, are not uncommon in exploratory studies [18].

\section{Validity and Reliability}

In discourse analytic research Jørgensen \& Phillip [13] state that the validity is connected to concepts like coherence and fertility. These concepts are relevant in the discussion of the validity of this study. The coherence of a study is present if there is an internal similarity between the ways the informants express vital factors. If the stated factors then also correlate with factors found in other studies, there will be an external coherence as well. Since it was possible to categorize 110 out of a total of 150 statements as belonging to the twelve factors of Figure 1, it proved that the external validity was quite high. The fact that informants referred to the same factors under different terms, and that they have been counted several times, indicated that the internal validity ${ }^{5}$ should be strong as well. Some of the new factors categorised had a similar internal validity. Informants repetitive stating of the same factor, using a variety of words showed that these factors also appeared reliable.

The fertility of this study is linked to the subquestions 2 - 4, (openness for new factors, new knowledge of any factor's substantiality and new ways of organizing the factors). It required a theoretical codification to construct such new categories of factors [17]. This was accomplished by using Figure 1's factorial manual to categorise statements. Thereby new factors of this present study were revealed. This way of constructing codes proved the study' fertility, it most likely strengthened its validity.

The reported problem of concept-validity linked to the concept inclusive education seemed to be minimised, due to the fact that the interviewer's definition was shared with the informants in two ways: (1) As a part of the interview guide which the informants received by mail in good time before the date of the interview; and (2) the oral talking over of the definition as an introduction to question 8. Most likely, this contributed to both the interviewer and the informants having the same comprehension of the concept. However, another key-concept, factor, might cause a validity problem. Important questions were: How fine-meshed should one delineate the criteria of a factor? What are the thresholds to identifying a new factor? The factors of Figure $\mathbf{1}$ were not explicitly criteria-described for each factor, and it is not hard to observe overlaps between them.

The emphasis on creating a safe climate for the interviews by using time initially for small talk, probably contributed to the informants' openness. This allowed them to speak freely and honestly, thereby

\footnotetext{
${ }^{5}$ Estimating internal validity by means of Cronbach's alpha is rarely seen in connection with discourse analytic approaches, according to Jørgensen \& Phillip, 2008 [13]. Such statistical measures lose reliability with low numbers of informants, too.
} 
strengthening the reliability of their stories. The interviewer's summing up of the content of the informants' explanations, inviting them to confirm or correct it, contributed likewise to the reliability. He also finalized the interviews by asking the informants whether they had something to add or alter. Hardly any comment or revision was uttered, which was interpreted as if the informants had been able to articulate their true and reliable points of view.

The impact of the contexts of the interviews on the reliability seemed weak since there were hardly any disturbances worth mentioning. The technical problem with the tape recorder during the interview of a couple did not influence the results since they have been excluded as informants.

Another legitimate question is whether interviewing a couple together might disturb the independency and freedom of the individual's statements. Most of the couples admitted that they had discussed the interview guide beforehand, and prepared themselves as to what to say. The pleasant atmosphere of the interview sessions stimulated them to jointly remember better, to agree on opinions, but also to express disagreements when their thoughts distended. The latter at times occurred, though not frequently. So the general impression is that the information shared was enriched, and that the informants articulated honest and reliable answers. However, one cannot exclude the possibility that they to a certain extent might have answered differently if they had been interviewed independently. Since two remember better than one, it is likely that interviewing one at a go would have led to both less information shared and less confirmed. In next turn this would have weakened both the study's validity and reliability. So, all in all, this point as well as the arguments above, contributes to conclude that the study has achieved both reasonably good validity and reliability.

\section{RESULTS AND DISCUSSIONS}

This section presents and discusses these subparagraphs: The numbers and the distributions of statements uttered; the frequencies of the factors of Figure 1 found; the appearance of new factors and their frequency; the discussions of which factors are considered substantial; the discussions of combining factors, including renaming logic factor-combinations; and the problem of describing too coarse-grained factors.
The Numbers and Distributions of Statements Uttered

The data included 150 statements that were classified as references to either the Figure 1 factorial manual or to new categories of factors. 110 statements referred to the former and 40 to the latter. Averagely each informant uttered 9.38 factorial statements. The distribution of statements among the informants varied from 1 to 19 .

How was this variance in uttered number of statements linked to informants' demographics? On the one hand simple counting showed that the number of statements articulated varied according to gender (women expressed averagely more statements than men); to age (those below 50 years uttered averagely more factor-statements than those over 50 year); and to number of years being a parent of a child with ID: Those with a child schooling for the time being stated more factors than those whose children attended regular schools some years ago. The latter some of the older informants were explicitly aware of, by saying it was hard to remember examples of good practice years ago. This biased variance linked to age was also emphasized by the fact that younger informants ( 6 out of 14) uttered approximately half of the statements. Their statements were more related to the current ideology of inclusive education, too. On the other hand the counting showed that the informants' level of education had no revealed impact on the number of factorial statements expressed. Based on these analyses it seems reasonable to conclude that the women informants, below 50 , had more impact on the knowledge generated in this study.

\section{Sub-Question 1: Which of the Factors, Disclosed in Current Literature, is Frequently Mentioned by the Informants?}

Table 3 shows both how frequently each of the factors of Figure 1 was mentioned, and examples of typical statements.

These factors of Table 3 fulfilled the first criterion of the concept frequently mentioned, i.e. articulated in at least ten statements by the parent-informants: (2) cooperation home-school; (3) particulars of classroom practice; (4) staff's quality, qualification and development; and (7) collaboration and co-ordination. That some informants talked of the same factor by using different wording, was interpreted as a signal that the informant emphasised this particular factor. Therefore, each statement was counted separately. 
Table 3: Identified Statements Related to Previously Found Factors, Figure 1's Figures in Brackets, NoS = Number of Statements Expressed; Nol = Number of Informants Expressing a Statement

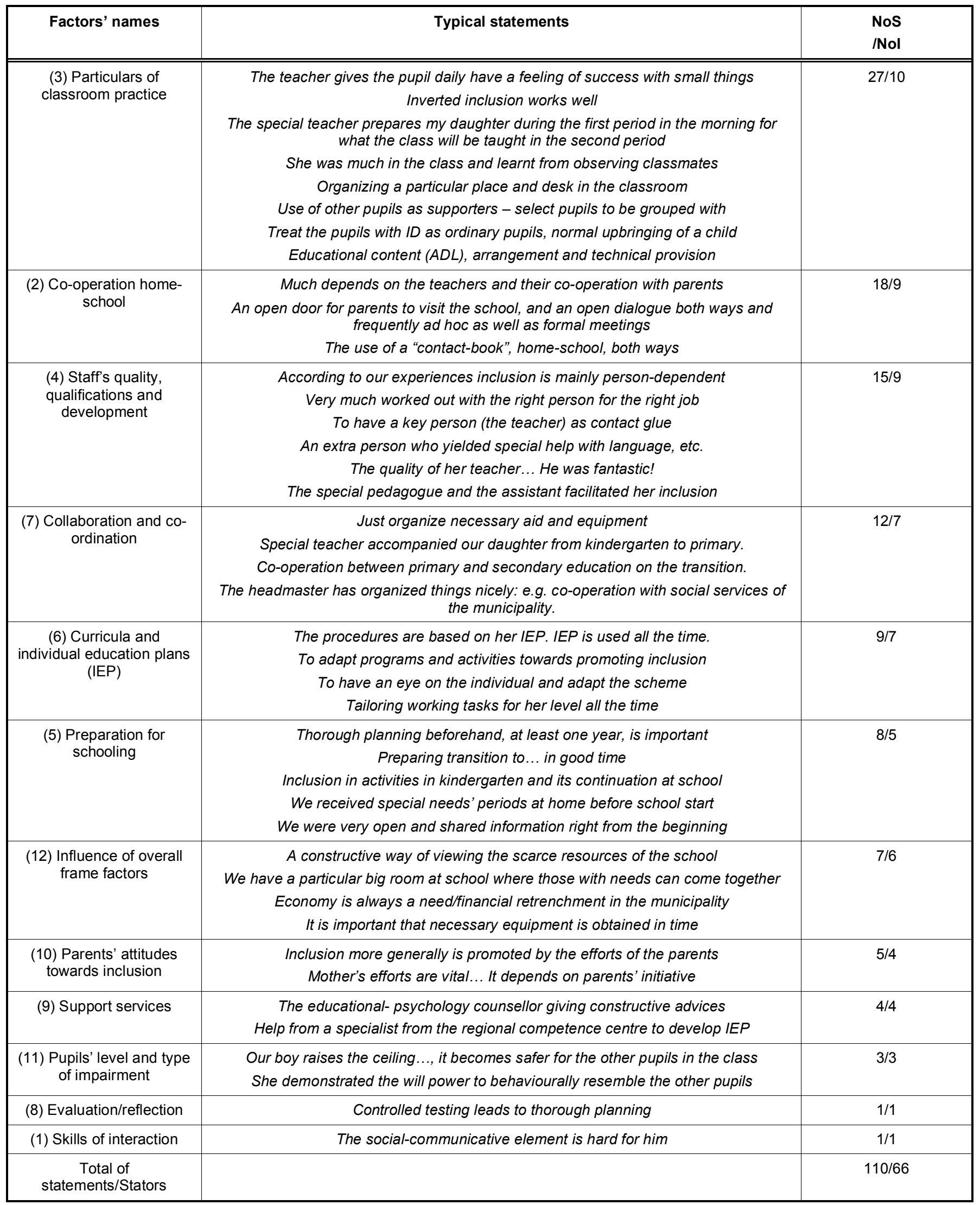


However, the second criterion of frequently mentioned, the factor should be expressed by at least 7 informants, should also be "satisfied". Table 3 shows that the same four factors fulfilled this criterion too. In addition, (6) curricula and IEP, was also referred to by 7 informants. Consequently, there were four factors among the twelve, namely factors (2), (3), (4) and (7), that explicitly fulfilled both the criteria of frequently mentioned, and thereby constituting the answer to research question 1 . In addition, factor (6) was very close to attaining the same status.

\section{Sub-Questions 2: Which New Factors are Disclosed?}

Analyses of the statements detected six new factors, as described in Table 4.

In the light of the criteria of frequently mentioned Table 4 shows that factor 13, the impact of positive attitudes towards inclusive education, fulfilled it, being articulated 18 times, by 11 informants. If one generalizes the key-concept of this factor, attitude, to also comprising parents' attitudes, as stated in factor 10 , the number of statements referring to this phenomenon, grows to $23(18+5)$, and informants mentioning it becomes 12 . These facts make "the attitude factor" the most widespread factor found, and the second highest in frequency of expression. The significance of positive attitudes, like care and support, is also emphasized in an Icelandic study [19].

Factor 14, the use of other arenas than the school facilities, fulfilled the second criterion of frequently mentioned, but lacked two mentions to reach the first criterion. Subsequently, it maintains the same status as factor 6, curricula and IEP.

The other four new factors were in a limited extent mentioned and by few informants only. One might, however, ask whether these factors are "new" in their nature. Factor 15 might be seen as a variant of factor 12 , influence of overall frame factors, since access to stable and transition-willing personnel might be a financial question in the educational sector. Factor 17 and 18 might be perceived an extension of factor 3 , particulars of classroom practice. Emphasizing them as separate factors makes it easier for practitioners of inclusive education to discover them and exploit them in efforts of prominent practice. Factor 16, partial use of segregated provisions..., is perhaps surprising, particularly because NAPDD-member-parents mostly spearhead inclusive education. However, this sample of informants might have individuals that hold an inbetween-position [20]. It means they agree that some kinds of segregated provision are necessary to attain a better inclusion at a local school. Practically they might have had bad experiences with negative attitudes of headmasters, lack of qualified personnel or bullying of their child in regular school [21]. At the same time they have also received necessary help from experts from special schools/resource-centres of special needs education. If this is the case, it relates well to the author's definition, stating metaphorically that "inclusion strives to become a bridge between normal and special teaching" [6].

The conclusive answer of research question 2 is that five new factors were identified and provisionally retained as separate factors. One factor, 13, was combined with an old factor, 10, and renamed the general impact of positive attitudes towards inclusive education, and it was particularly frequently mentioned.

\section{Sub-Question 3: Which Factors are Considered Substantial?}

The analyses revealed that all in all seven factors were frequently mentioned by the informants. This renamed factor, the general impact of positive attitudes towards inclusive education, was very numerously articulated. Because of its impressive support and its importance in other parent-informant-studies [22, 23], it must be regarded as substantial, at least from the parents' perspective.

If one applies this idea of combining key concepts in other factors as well, one observes that the concepts of co-operation (factor 2) and collaboration and coordination (factor 7) refer to the same processes of working together for attaining a goal efficiently. Factor 2 focuses more the idea of unifying efforts between the two institutions, home and school; while factor 7 refers more to the same within the sole institution of school. If one combines the two factors and renames it extensive co-operation and co-ordination, one observes that the informants referred to it 30 times, and it was mentioned by eleven informants. Consequently it was more frequently expressed (30 to 24 ) and almost as equally distributed among the informants (11 to 12 ) as the factor positive attitudes. Thus this factor is also seen as substantial.

Figure 1's factors 3 and 4 are both high-scored in Table 3: One observes that 10 informants mentioned particulars of classroom practice 27 times; while 9 
Table 4: Statements Indicating New Factors Found

\begin{tabular}{|c|c|c|}
\hline $\begin{array}{c}\text { Factor's name and } \\
\text { number }\end{array}$ & Typical statements & $\begin{array}{c}\text { NoS } / \\
\text { Nol }\end{array}$ \\
\hline $\begin{array}{l}\text { (13) The impact of positive } \\
\text { attitudes towards inclusive } \\
\text { education }\end{array}$ & $\begin{array}{l}\text { "There are so many young people with positive attitudes towards people with disabilities"; "Primarily, } \\
\text { the leadership of the school must have a positive attitude"; "To be included at school and in the } \\
\text { society goes hand in hand"; "To train those with ID helps them to attain better life - this relates to } \\
\text { attitudes"; "The attitudes of the support services"; "The right attitude towards inclusion among those } \\
\text { employed in kindergartens/schools"; "Attitudes and will are two sides of the same issue"; "The right } \\
\text { education to the right person with positive attitudes is the master key to attain inclusion". }\end{array}$ & $18 / 11$ \\
\hline $\begin{array}{l}\text { (14) The use of other } \\
\text { arenas than the school } \\
\text { facilities }\end{array}$ & $\begin{array}{c}\text { "The use of other arenas than the classroom, like swimming and riding. It opens for inverted } \\
\text { inclusion both in the school program and in leisure time activities"; "Parents opened a "bullying-free" } \\
\text { club at home for children in the neighbourhood. It led to inclusion and a feeling of belonging"; "She } \\
\text { receives natural training of ADL-skills by the local people"; "Greeting each other during free time, } \\
\text { both parents and children"; "To invite and be invited to birthday parties and other events, as well as } \\
\text { organizing a group for the breaks at school". }\end{array}$ & $8 / 7$ \\
\hline $\begin{array}{l}\text { (15) The impact of stable } \\
\text { and transitional personnel }\end{array}$ & $\begin{array}{l}\text { "Avoid turnover of caring personnel"; "During the transitional period from child level to youth level, a } \\
\text { teacher accompanied him. It appeared reasonable for the sake of inclusion"; "The person in charge } \\
\text { of him in the kindergarten accompanied him to the primary school and continued there." }\end{array}$ & $5 / 5$ \\
\hline $\begin{array}{l}\text { (16) Partial use of } \\
\text { segregated provision } \\
\text { (special classes/schools) as } \\
\text { a help for inclusion }\end{array}$ & $\begin{array}{l}\text { "Attending a special school is not necessarily causing a problem about being included in playing } \\
\text { games in the local street"; "He received special education partly separately there and then. Even so } \\
\text { he is still included by his age mates who always greet him and talk with him } 30 \text { years later"; "At the } \\
\text { youth level she is given more separate training, but in some subjects she benefits from participating } \\
\text { in the class, and she always joins the school lunch. In that way she is still much a part of the class". }\end{array}$ & $4 / 3$ \\
\hline $\begin{array}{l}\text { (17) Making use of the } \\
\text { talents of the pupil with ID to } \\
\text { promote inclusion }\end{array}$ & $\begin{array}{c}\text { "Use of her competence in particular subjects"; "Celebrating her specific achievements with the } \\
\text { whole class, like doing shopping on her own for the first time"; "Our child raises the ceiling of the } \\
\text { classroom because he makes it easier for the classmates to ask silly questions". }\end{array}$ & $3 / 2$ \\
\hline $\begin{array}{l}\text { (18) The other pupils as a } \\
\text { resource for accomplishing } \\
\text { inclusive education }\end{array}$ & $\begin{array}{c}\text { "She was placed together with the "bully- boys", and they took on the role of caretaking, and } \\
\text { discovered the joy of being helpers"; "A group of Christian co-pupils saw that she was bullied, and } \\
\text { they opened up their group for her, both during breaks and leisure time". }\end{array}$ & $2 / 2$ \\
\hline $\begin{array}{c}\text { Total number of } \\
\text { statements/stators }\end{array}$ & & $40 / 29$ \\
\hline
\end{tabular}

informants uttered staff's qualities, qualifications and development 15 times. They are both assessed as substantial, not least because they are also well substantiated in other studies $[5,6]$. One should, however, notice that when parents talked of staff's qualities etc., they only referred to the personnel's quality and qualification - not to how they can develop professionally. Thus this study does not allude to administrative provisions for stimulating professional development of staff generally, or developing their practical and theoretical skills in inclusive education. This seems quite natural since parents rarely have insight into how staff's further development might be organised. Consequently it is reasonable to argue that this factor should be "reduced" to comprise only staff's quality and qualifications.

Table 3's last factor, skills of interaction, was hardly mentioned by the informants, and thus is not assessed to be substantial - even if it has much support in other studies (see Table 1). Why this difference was obtained in this study is hard to explain. It might be caused by the use of a rather general interview question, not focusing particularly on interaction skills. Notwithstanding, it might be reasonable to assess this factor's absence as a sign of unawareness or downgrading among these parents: It was not among their foremost experiences.

Because of low support among the informants none of the other factors identified in Tables $\mathbf{3}$ and $\mathbf{4}$ obtains the status of substantiality. The use of other arenas than the school facilities was closest to reaching this status. It is so promising that it ought to be taken into serious consideration when planning for and implementing inclusive education. The same applies to the other insubstantial factors, because successful inclusive education requires awareness of a multitude of factors interacting with each other, and it depends on the best values and attitudes among the actors implementing its ideology.

However, this study shows and argues that the following four factors meet the criteria for substantiality: (1) the general impact of positive attitudes towards inclusive education; (2) extensive co-operation and coordination; (3) particulars of classroom practice; and (4) 
staff's quality and qualifications. They are claimed to be basic for attaining inclusive education. Thus they form the foundation of the metaphoric model: "the schoolhouse of inclusive education" (Figure 2).

\section{Sub-Question 4: Which Factors might be Combined, and Possibly Renamed?}

From the arguments above one observes that three pairs of factors ( 2 and $7 ; 10$ and $13 ; 12$ and 15) were amalgamated; and renamed. One might ask whether there are arguments for merging and renaming any of the non-substantial factors as well. If so, it should be possible to combine some of these factors to provide fewer essential categories and thereby produce a synopsis, easier to remember. Figure 2 presents a visualized synopsis, attending to this: The basement contains the substantial factors found. The ground floor illustrates a fusion of the unsubstantial factors into three superior factors, "manufactured" this way: Firstly, factors referring to educational processes were fused together: preparation for schooling, which refers to the process of planning, was combined with evaluation and reflection, which relates to two other essential processes of education, and renamed to this factor: (6) Importance of thorough planning, evaluation and reflection on practice. Secondly, factors dealing with qualities of pupils being together were merged to a common renamed factor: (7) Inventive use of the pupils' readiness and talents for inclusive education. It consists of these identified factors: skills of interaction; pupils' level and type of impairment; making use of the talents of the pupils with ID; and use of the other pupils

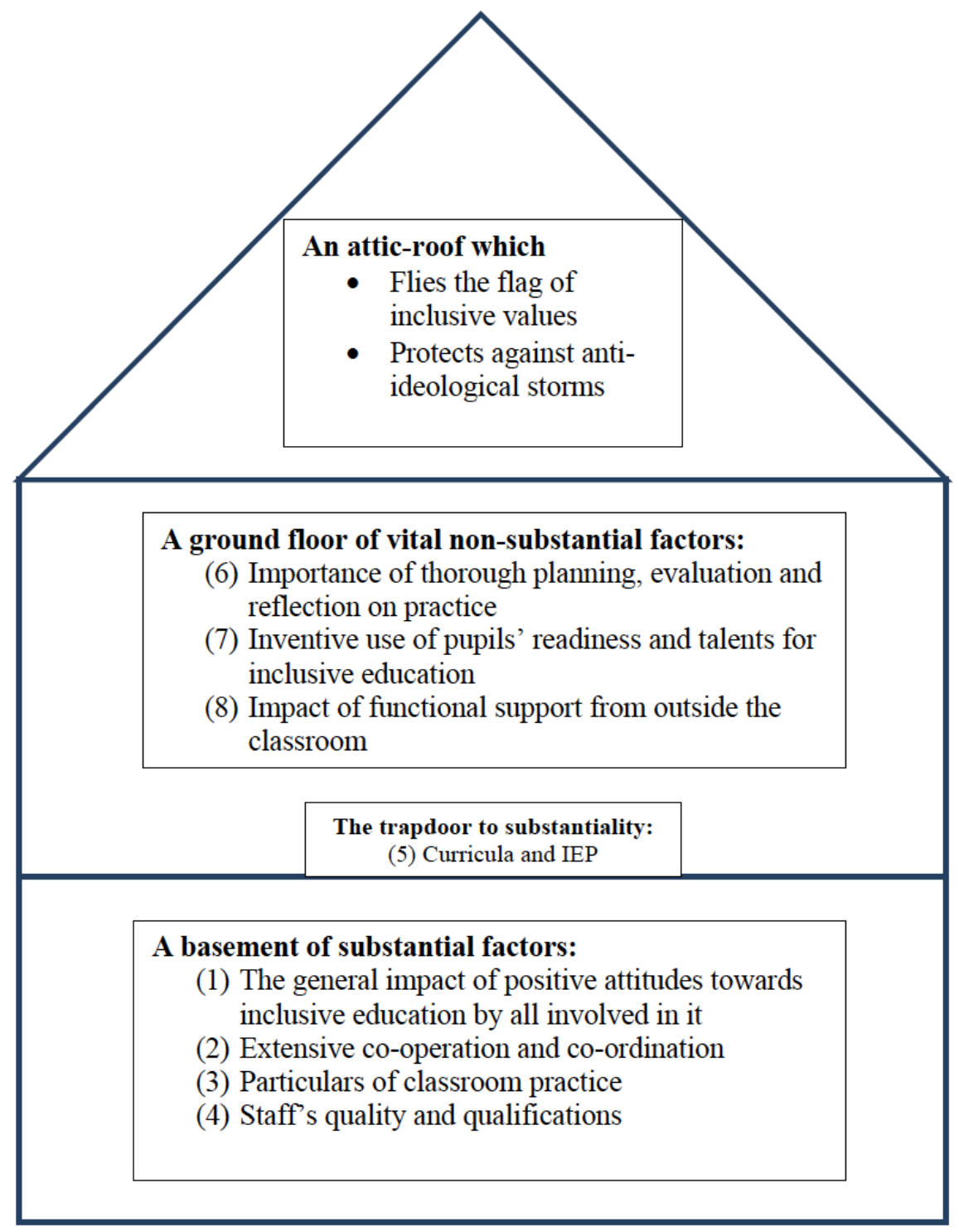

Figure 2: "The school-house of inclusive education": Substantial factors (basement), other vital factors (ground floor), and promoting fights of ideology (the attic and roof). 
as a resource. Lastly, a third common renamed factor was established, (8) impact of functional support from outside the classroom, by combining frame factors; stable personnel; support services; and partly use of segregated provisions.

We were then left with one identified factor, (5) curricula and IEP, which had not been re-categorized. It is partly a process factor since it refers to planning, and it is partly of great relevance for classroom practice [24]. Since it was also frequently spoken of by the parents, it almost qualified for substantiality. Therefore it was kept as a separate factor, placed in Figure $\mathbf{2}$ at the trapdoor to substantiality. However, to perform optimally within a pragmatic best practice research perspective the Figure 2's factor-rooms must be protected by an attic-roof containing the values of inclusion, strong enough to resist any anti-ideological storm. To make a sustainable roof one needs studies rooted in a critical approach [5]. The "stormy" discussions within inclusive education will expectedly continuous. Consequently, the methodological concept discursive struggle remains rather permanently useful; both in future research and practice.

The answer of sub-question 4 is that this study identified a total of 18 factors, of which 16 have been combined and renamed to 6 factors of Figure 2, while two have been kept as they were originally designated: (3) particulars of classroom practice and (5) curricula and IEP.

\section{Overly Coarse-Grained Factors - A Validity Problem}

The factors described both in Bachke's former literature reviews [5, 6], as well by Haug [3], by Eggertsdóttir et al. [2], and talked of by parents in this study are rather coarse-grained. They become even rougher when several categories of factors are combined. Moreover, it is easy to observe overlaps between the factors. Such overlaps raise questions like (a) how much variance must be present to constitute a separate factor; and (b), is it possible to avoid factorial overlaps in a complex research field like inclusive education? These questions confront the researcher with the dilemma of concept-validity. On the one hand, to make user-friendly surveys one must establish comprehensive categories, which, on the other hand, are too broad to give precise descriptions for repeatable practice. One slides easily into showing findings that say everything without stating anything. Arnesen [25] alludes to such self-evident truths by stating that to attain inclusive education of high quality one should only use skilled teachers, practising topscaled education.

However, the summaries of several empiricalpragmatic studies as well as findings deduced from studies using either a critical or a human rights perspective $[6,7]$, jointly suggest to "pathways to inclusion" [2] that point directly towards improved practice. In addition, to acquire more detailed knowhow of this practice, for instance "particulars of classroom practice", one can either study the underlying references of the surveyed studies; or one might dive deeper into the paragraphs of "A guide to staff development" which are based on successful practices of inclusive education [2]. Likewise, to elucidate the qualities of particularly successful teachers one might look at the arguments for research on and descriptions of his/her authenticity made by Laursen [26]. Hopefully, such descriptions might inspire other teachers to improve their practice. In the same way, it is a reasonable expectation that knowledge of Figure 2 might lead to similar results.

\section{CONCLUSIONS}

The general research question of this study is: Which factors do parents of offspring with intellectual disability experience as promoting inclusive education for their children? Results and discussions showed that:

1) Parent-informants emphasized to a large extent the same promoting factors of inclusive education as shown and argued for in the reviews of relevant literature.

2) Parents also articulated six additional factors.

3) Based on the results, these four factors were evaluated as substantial: The general impact of positive attitudes towards inclusive education by all involved in it; extensive co-operation and coordination; particulars of classroom practice; and staff's quality and qualifications. One more factor almost attained substantiality: curricular and IEP.

4) Arguments for combining some of the study's identified factors into superordinate factors with revised names were presented and resulted in 18 factors became 8 . These 8 factors are placed in a theoretical model, baptized metaphorically the school-house of inclusive education (Figure 2). The purpose of Figure $\mathbf{2}$ is to visualise important factors contributing successfully to 
inclusive education, and thereby illustrate the main conclusion of the general research question.

5) The validity-problem of relying on too coarsegrained factors and using them as lodestars for improving practice was discussed.

Lastly, this study has chosen to adhere to an empirical-pragmatic research perspective. The method of interviewing parents of children with ID limits it to the impressions and interpretations of only one group of actors involved in inclusive education. Consequently, one must be cautious in generalizing the findings to parents of "normal" children as well as to other educational actors like teachers, pupils, administrative personnel, and school-politicians. Both to confirm the findings of this study and to achieve a more complete picture of positively contributing factors there is a need for broader methodological approaches like Eggertsdóttir et al. [2]. To add valuable knowledge it would be particularly interesting to interview a sample of all the informant-groups mentioned above, at schools well-known for successful inclusive education, to focus a best-practice approach.

\section{REFERENCES}

[1] Thomas G. Inclusive schools for an inclusive society. $\mathrm{Br} \mathrm{J}$ Special Educ 1997; 24: 103-107. http://dx.doi.org/10.1111/1467-8527.00024

[2] Eggertsdóttir R, Marinósson G. Pathways to inclusion. A guide to staff development, eds. Reykjavik: Háskólaútgáfan, University of Iceland Press 2005.

[3] Haug P. Approaches to empirical research on inclusive education. Scandinavian J Disability Res 2010; 12: 199-209. http://dx.doi.org/10.1080/15017410903385052

[4] UNESCO. The Salamanca Statement and a Framework of Special needs of Education, Paris: UNESCO 1995.

[5] Bachke CC. Which factors promote inclusion of pupils with impairments in local schools? What do Nordic scholars say about it? Proceedings: Society, integration, education. International conference, Feb, 27th-28th, 2009, Rezekne Augstskola, Latvia 2009; pp. 481-94.

[6] Bachke CC. Inclusion of pupils with disabilities: Research perspectives and promising factors. A literature review. Proceedings of the International Scientific Conference, Society, integration, education, May $27^{\text {th }}-28^{\text {th }}$, Volume I, Rezekne, Latvia, ISSN 1691-5887 2011a; pp. 345-362.
[7] Tetler S. Den inkluderende skole - fra vision til virkelighed. København: Socialpædagogiks bibliotek, Gyldendal uddannelse 2000 .

[8] Wilkinson LA. A best practice guide to assessment and intervention for autism and Asperger syndrome in schools, London: Jessica Kingsley 2010.

[9] http://www.who.int/classifications/icd/en/bluebook.pdf, 22.09.2010.

[10] Emanuelsson I, Haug P, Persson B. Inclusion in some Western European countries, Different policy rhetorics and school realities; In: Mitchell D., ed. Contextualising inclusive education; evaluating old and new international perspectives. London: Routledge 2005; pp.114-38.

[11] Alenkær R, Ed. Den inkluderende skole: en grundbog. København: Frydenlund 2008.

[12] Kvale S, Brinkmann S. Det kvalitative forskningsintervju, Oslo: Gyldendal akademisk 2009.

[13] Jørgensen MV, Phillips L. Diskursanalyse som teori og metode. $6^{\text {th }}$ ed. Frederiksberg DK: Roskilde Universitetsforlag 2008.

[14] http://www.nfunorge.org/view.cgi?\&link_id=0.1067.41227\&se ssion_id=0, 02.08.2012.

[15] Ringdal K. Enhet og mangfold, Bergen: Fagbokforlaget 2001

[16] Charmaz K. Constructing grounded theory: A Practical guide through qualitative analysis. London: SAGE 2006.

[17] Fejes A, Thornberg R, editors. Handbok i kvalitativ analys. Eds. Stockholm: Liber 2009.

[18] Creswell JW. Research design: Qualitative, quantitative, and mixed methods approaches, Thousand [Oaks, CA: SAGE 2003.

[19] Marinósson G. Tálmar og tækifæri. Menntun nemenda með proskahömlun á Íslandi. Reykjavík: Háskólaútgáfan 2007.

[20] Dalen M, Ogden T. Spesialpedagogikk og spesialpedagogiske tiltak. In Rygvold A-L, Ogden T, editors. Innføring i spesialpedagogikk, 4.utg., Oslo: Gyldendal Akademisk 2008; 383-414.

[21] Bjarnason DS. Social policy and social capital: parents and exceptionalities 1974-2007. New York: Nova Science Publisher, Inc. 2010.

[22] Tsai EH-L, Fung L. Parents' Experiences and Decisions on Inclusive Sport Participation of Their Children with Intellectual Disabilities. Adapted Physical Activity Quarterly 2009; 26: 151-71.

[23] Cole BA. "Good faith and effort"? Perspectives on educational inclusion, Disability, Handicap and Society 2005 20: $331-44$ http://dx.doi.org/10.1080/09687590500060794

[24] Bachke CC. Individuelle opplæringsplaner - mye brukt, men lite utforsket. Spesialpedagogikk 2011; no.10: 4-17.

[25] Arnesen A-L. Det pedagogiske nærværet. Inkludering i møte med elevmangfoldet. Oslo: Abstrakt forlag 2006.

[26] Laursen PF. Den autentiske læreren. Bli en god og effektiv lærer - hvis du vil. Oslo: Gyldendal Akademisk 2004.

Received on 28-06-2013

DOI: http://dx.doi.org/10.6000:2292-2598.2013.01.01.7

(c) 2013 Carl Chr. Bachke; Licensee Lifescience Global.

This is an open access article licensed under the terms of the Creative Commons Attribution Non-Commercial License (http://creativecommons.org/licenses/by-nc/3.0/) which permits unrestricted, non-commercial use, distribution and reproduction in any medium, provided the work is properly cited. 